Sari, et al/Jurnal Ekonomi Syariah Teori dan Terapan Vol. 6 No. 10 Oktober 2019: 2008-2023; FAKTORFAKTOR YANG MEMPENGARUHI NILAI PERUSAHAAN PADA PERUSAHAAN PERDAGANGAN, JASA DAN INVESTASI YANG TERDAFTAR DI ISSI

\title{
FAKTOR-FAKTOR YANG MEMPENGARUHI NILAI PERUSAHAAN PADA PERUSAHAAN PERDAGANGAN, JASA DAN INVESTASI YANG TERDAFTAR DI ISSI ${ }^{1}$
}

\author{
Nadia Laksmita Sari \\ Departemen Ekonomi Syariah-Fakultas Ekonomi dan Bisnis-Universitas Airlangga \\ Email: nadia.laksmita.sari-2015@feb.unair.ac.id \\ Puji Sucia Sukmaningrum \\ Departemen Ekonomi Syariah-Fakultas Ekonomi dan Bisnis-Universitas Airlangga \\ Email: puji.sucia@feb.unair.ac.id
}

\begin{abstract}
:
This research aims to find out the factors that influence company value (Tobin's Q) trade, services and investment registered at ISSI during 2013-2017. This study uses a quantitative approach with panel data regression analysis techniques. The results of this study shows that managerial ownership, Return On Equity, Current Ratio, Debt To Asset Ratio, Total Assets Turnover Ratio simultaneously have a significant effect on firm value (Tobin's Q). Partially managerial ownership variable has a significant negative effect, the Return On Equity variable has a positive significant effect, the Current Ratio and Debt To Asset Ratio variables have a positive insignificant effect and the Total Assets Turnover Ratio has a negative but not significant effect on firm value (Tobin's $Q$ ).
\end{abstract}

Keywords:Managerial Ownership, Return On Equity, Current Ratio, Debt to Asset Ratio, Total Asset Turnover Ratio, Tobin's Q.

\section{PENDAHULUAN}

Islam memandang harta dengan acuan akidah yang disarankan Al-Quran yakni mempertimbangkan kesejahteraan umat manusia, alam, masyarakat dan hak milik. Islam mendorong setiap manusia untuk bekerja dan meraih sebanyakbanyaknya materi. Investasi merupakan salah satu ajaran dari konsep islam selain sebagai pengetahuan sekaligus merupakan hakikat dari sebuah ilmu dana mal, oleh karena itu investasi sangat dianjurkan bagi setiap muslim. Hal tersebut dijelaskan dalam Al-Quran surat Al- Hasyr (59):18 sebagai berikut:

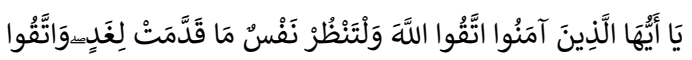

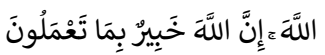

$$
\begin{aligned}
& \text { yā ayyuhallażina āmanuttaqullāha } \\
& \text { waltanz̧ur nafsum mā qaddamat ligad, }
\end{aligned}
$$

wattaqullāh, innallāha khabīrum bimā ta'malun

Artinya: "Hai orang-orang yang beriman, bertakwalah kepada Allah dan hendaklah setiap diri memperhatikan apa yang telah diperbuatnya untuk hari esok (akhirat); dan bertakwalah kepada Allah, sesungguhnya Allah Maha Mengetahui apa yang kamu kerjakan". (QS. Al-Hasyr (59):18. Departemen Agama)

Investasi salah satu kegiatan yang bertujuan untuk mendorong pertumbuhan ekonomi di Indonesia yang bisa dilakukan salah satunya di Pasar Modal (Buharuddin, 2008:130). Sebagai negara yang memiliki penduduk muslim terbanyak di dunia, Indonesia memiliki pasar modal syariah terbesar di dunia untuk mengakomodir para investor muslim di Indonesia yang

\footnotetext{
${ }^{1}$ Jurnal ini merupakan bagian dari skripsi dari Nadia Laksmita Sari, NIM: 041511433192 , yang diuji pada tanggal 18 Juli 2019.
} 
Sari, et al/Jurnal Ekonomi Syariah Teori dan Terapan Vol. 6 No. 10 Oktober 2019: 2008-2023; FAKTORFAKTOR YANG MEMPENGARUHI NILAI PERUSAHAAN PADA PERUSAHAAN PERDAGANGAN, JASA DAN INVESTASI YANG TERDAFTAR DI ISSI

ingin berinvestasi berbasis syariah dan memberikan manfaat bagi pemodal yang berinvestas di bursa efek (Yuliana, 2010:47). Salah satu indeks saham yang diluncurkan pertama oleh Bursa Efek Indonesia (BEI) adalah Indeks Saham Syariah Indonesia (ISSI) yaitu indeks yang mengukur performa harga seluruh saham yang dinyatakan sebagai saham syariah sesuai dengan Daftar Efek Syariah (DES) yang ditetapkan oleh Otoritas Jasa Keuangan (OJK).

Terdapat berbagai macam sektor saham syariah yang tersedia di pasar modal, salah satunya yaitu sektor perdagangan jasa dan investasi. Sektor perdagangan jasa dan investasi meliputi retail, restoran, hotel, periklanan, percetakan, perawatan kesehatan, computer, perusahaan investasi dan lainnya sehingga dengan kata lain sektor ini merupakan sektor yang kuat dikarenakan dibutuhkan masyarakat sehari-hari. Perkembangan yang beragam tersebut menciptakan peluang bisnis yang besar di sektor jasa, sehingga dapat menyerap permintaan konsumen yang tinggi, dan dapat menarik perhatian para investor untuk berinvestasi Herlina (2015).

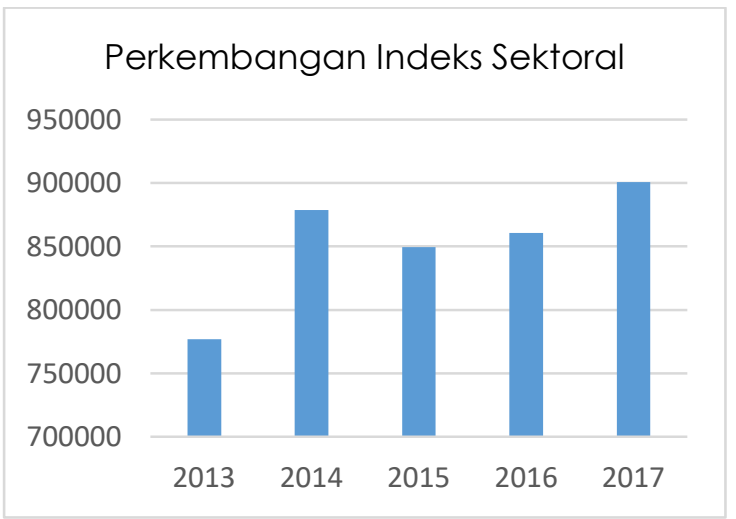

Sumber: www.ojk.go.id

Gambar 1.

\section{Perkembangan Indeks Sektoral}

\section{Perdagangan, Jasa dan Keuangan}

Pada gambar 1 di atas menjelaskan perkembangan indeks sektor pada perdagangan jasa dan investasi di Indonesia. Perkembangan indeks sektor dari tahun ke tahun mengalami fluktuatif. Tercatat pada tahun 2017 merupakan tingkat perkembangan indeks sektoral tertinggi hingga mencapai 900.697. Beberapa penelitian yang pernah diadakan oleh Badan Pusat Statistik (2018) mengumumkan sektor perdagangan jasa dan investor menjadi salah satu dari lima sektor yang menyumbang PDB terbesar setelah sektor industri pengolahan. Sektor perdagangan jasa dan investasi menyumbang $13,12 \%$ yang tumbuh sebesar $4,96 \%$ dari tahun sebelumnya yang hanya tumbuh $4,61 \%$.

Implementasi

penerapan corporate governance menjadi peluang besar bagi perusahaan untuk meraih berbagai manfaat termasuk kepercayaan investor terhadap perusahannya. Memaksimalkan nilai perusahaan adalah tujuan jangka panjang perusahaan, dalam prosesnya akan muncul adanya agency problem antara manajer dan pemegang saham. Kepemilikan manajerial pada nilai perusahaan selalu menjadi topik khusus dalam keuangan perusahaan (Denis McConnell, 2003). Secara umum, kepentingan manajer dan pemegang saham tidak sepenuhnya 
Sari, et al/Jurnal Ekonomi Syariah Teori dan Terapan Vol. 6 No. 10 Oktober 2019: 2008-2023; FAKTORFAKTOR YANG MEMPENGARUHI NILAI PERUSAHAAN PADA PERUSAHAAN PERDAGANGAN, JASA DAN INVESTASI YANG TERDAFTAR DI ISSI

selaras. Konflik yang timbul dari kepentingan manajer dan para pemegang saham akanmenimbulkan agency problem yang akan mengurangi nilai perusahaan. Peningkatan kepemilikan manajerial dari level yang rendah tidak hanya membantu menghubungkan kepentingan manajer dan pemegang saham, tetapi juga mengarah kepada pengambilan keputusan yang lebih baik yang mengarah pada nilai perusahaan yang tinggi Endraswati (2012).

Informasi kinerja perusahaan melalui laporan keuangan menjadi hal penting bagi investor. Jika laporan keuangan menunjukkan kinerja perusahaan yang bagus dilihat dari seringnya mendapatkan keuntungan, maka hal itu akan mempengaruhi harga saham perusahaan tersebut (Hamdani, 2016:120). Analisis perusahaan merupakan analisis yang menghubungkan dan memperkirakan harga saham dimasa yang akan datang dengan mengestimasi nilai faktor fundamental yang digunakan berdasarkan beberapa rasio keuangan. Indikator pengukuran kinerja perusahaan diantaranya rasio profitabilitas, rasio likuiditas, rasio solvabilitas, rasio aktivitas. Menurut penelitian Monika (2014) yang menyakatakan bahwa return on equity memiliki pengaruh terhadap nilai perusahaan. Kemudian Kahfi (2018) yang menyatakan bahwa current ratio, total assets turnover berpengaruh positif terhadap nilai perusahaan. Serta penelitian yang dilakukan Inggi (2014) menyatakan bahwa debt to asset ratio yang memiliki pengaruh terhadap nilai perusahaan. Berdasarkan variabel yang digunakan pada penelitian sebelumnya, pada penelitian ini menggunakan variabel yang berasal dari corporate governance dan faktor fundamental untuk mengetahui faktor yang mempengaruhi nilai perusahaan (Tobin's Q) pada perusaaan perdagangan, jasa dan investasi yaitu menggunakan variabel kepemilikan manajerial, Return On Equity, Current Ratio, Debt to Asset Ratio, Total Assets Turnover Ratio

\section{LANDASAN TEORI DAN PENGEMBANGAN HIPOTESIS}

Perspektif hubungan keagenan merupakan dasar yang digunakan untuk memahami corporate governance. Teori ini menjelaskan bahwa adanya konflik hubungan sebuah kontrak antara agen dengan prinsipal. (Ujiyantho, 2007) Faktor pemicu terjadinya masalah keagenan karena adanya asimetris informasi (asymmetric information). Dalam banyak kasus, agenlah yang memiliki keunggulan dalam memiliki informasi diatas prinsipal, alasannya mungkin keterlibatan langsung dalam operasional perusahaan. Asimetris informasi dapat dilihat dari kegagalan pasar yang menyebabkan alokasi sumber daya yang tersedia tidak efisien (Magness, 2008).

Struktur kepemilikan merupakan jenis kepemilikan yang memegang saham terbesar dalam suatu perusahaan 
Sari, et al/Jurnal Ekonomi Syariah Teori dan Terapan Vol. 6 No. 10 Oktober 2019: 2008-2023; FAKTORFAKTOR YANG MEMPENGARUHI NILAI PERUSAHAAN PADA PERUSAHAAN PERDAGANGAN, JASA DAN INVESTASI YANG TERDAFTAR DI ISSI

(Wahyudi dan Pawestri, 2006; dalam Sabrina, 2010). Struktur kepemilikan merupakan suatu mekanisme untuk mengurangi konflik antara manajemen dan pemegang saham (Faisal, 2005; dalam Sabrina, 2010). Struktur kepemilikan perusahaan memiliki peranan penting dalam hubungan kebijakan kewajiban perusahaan dimana kepemilikan perusahaan mempengaruhi control pada mayoritas pemilik saham dan kebijakan manajemen. Berdasarkan beberapa definisi diatas, maka struktur kepemilikan akan memiliki motivasi yang berbeda dalam memonitor perusahaan serta manajemen dan dewan direksinya. Struktur kepemilikan memiliki kemampuan untuk mempengaruhi nilai perusahaan dan kinerja perusahaan. Struktur kepemilikan terdiri dari kepemilikan saham oleh manajer dan direksi, kepemilikan saham oleh pihak institusi dan kepemilikan saham oleh pihak investor individual (Sisca, 2011: 41).

\section{Nilai Perusahaan}

Nilai perusahaan diindikasikan dengan menggunakan nilai Tobin's $Q$. Semakin tinggi nilai Tobin's $Q$, maka akan berdampak pada semakin baiknya tingkat kepercayaan pasar atas prospek perusahaan pada masa yang akan datang. Karena apabila nilai perusahaan tinggi dapat mengindikasikan bahwa tingkat kemakmuran para investornya juga tinggi. Nilai Tobin's $Q$ dapat diketahuidengan nilai pasar saham, yaitu jumlah saham biasa yang beredar dikali dengan harga penutupan, dijumlahkan dengan hutang dan dibagi total aset perusahaan. (Rahmantio, 2018)

\section{Kepemilikan Manajerial}

Kepemilikan

manajerial merupakan kondisi di mana manajer perusahaan merangkap jabatan sebagai manajemen perusahaan sekaligus pemegang saham yang turut aktif dalam pengambilan keputusan. Manajer dalam menjalankan operasi perusahaan seringkali bertindak bukan untuk memaksimumkan kemakmuran pemegang saham, melainkan justru tergoda untuk meningkatkan kesejahteraannya sendiri. Kondisi tersebut akan mengakibatkan munculnya perbedaan kepentingan antara pemegang saham dengan manajerial. Adanya kepemilikan manajerial dipandang dapat menyelaraskan potensi perbedaan kepentingan antara pemegang saham luar dengan manajemen (Jensen dan Meckling, 1976: 339). Selaras dengan Tarigan, Josua dan Yulius Yogi Christiawan (2007: 2) yang menyatakan bahwa dalam perusahaan dengan kepemilikan manajerial, manajer yang sekaligus pemegang saham tentunya akan menyelaraskan kepentingannya sebagai manajer dengan kepentingannya sebagai pemegang saham.

Analisis fundamental menyatakan bahwa setiap investasi saham mempunyai landasan yang kuat yang disebut dengan nilai intrinsic yang dapat ditentukan 
Sari, et al/Jurnal Ekonomi Syariah Teori dan Terapan Vol. 6 No. 10 Oktober 2019: 2008-2023; FAKTORFAKTOR YANG MEMPENGARUHI NILAI PERUSAHAAN PADA PERUSAHAAN PERDAGANGAN, JASA DAN INVESTASI YANG TERDAFTAR DI ISSI

melalui suatu analisis terhadap kondisi perusahaan pada saat sekarang. Secara umum terdapat 2 pendekatan yang sering digunakan oleh investor untuk menganalisis dan menilai saham di pasar modal yaitu analisis fundamental dan analisis teknikal (Bodie et al, 2009). Menghitung kondisi perusahaan biasanya dilakukan dengan menggunakan rasiorasio keuangan. Rasio-rasio keuangan secara garis besar dibagi kedalam 5 kategori yaitu profitabilitas, likuiditas, solvabilitas, aktivitas, dan pasar (Weston; Copeland, 1992). Analisis fundamental berkaitan dengan penilaian kinerja perusahaan mengenai efektivitas dan efisiensi perusahaan dalam mencapai sasarannya (Stoner et al. 1995).

\section{Return on Equity}

Return on Equity adalah rasio yang mengukur kemampuan dalam menghasilkan laba dengan mengukur return atas modal sendiri. Apabila ROE meningkat maka akan mengakibatkan harga saham perusahaan meningkat, sehingga akan meningkatkan profitablitas yang dinikmati oleh pemegang saham. Menurut Sasongko \& Wulandari (2006), menyatakan bahwa ROE merupakan tingkat pengembalian modal yang telah diinvestasikan oleh pemilik perusahaan (pemegang saham biasa). Semakin tinggi hasil pengembalian atas ekuitas berarti semakin tinggi pula jumlah laba bersih yang dihasilkan dari setiap rupiah dana yang tertanam dalam ekuitas. Sebaliknya, semakin rendah hasil pengembalian atas ekuitas berarti semakin rendah pula jumlah laba bersih yang dihasilkan dari setiap rupiah dana yang tertanam dalam ekuitas.

\section{Current Ratio}

Rasio lancar merupakan ukuran yang paling umum digunakan untuk mengetahui kesanggupan memenuhi kewajiban jangka pendek, oleh karena itu rasio tersebut menunjukan seberapa jauh tuntutan dari kreditor jangka pendek dipenuhi oleh aktiva yang diperkirakan menjadi vang tunai dalam periode yang samadengan jatuh tempo hutang. Menurut Hanafi dan Halim (2009, hal.204), bahwa:"Rasio lancar dihitung dengan membagi aktiva lancar dengan hutang lancar. Rasio ini menunjukan besarnya kas yang dipunyai perusahaan ditambah asset-asset yang bisa berubah menjadi kas dalam waktu satu tahun, relatif terhadap besarnya hutang - hutang yang jatuh tempo dalam jangka waktu dekat (tidak lebih dari 1 tahun), pada tanggal tertentu seperti tercantum pada neraca".

\section{Debt to Asset Ratio}

Debt to Total Assets ratio merupakan rasio utang yang digunakan untuk maengukur perbandingan antara total utang dengan total aktiva. Dengan kata lain, seberapa besar aktiva perusahaan dibiayai oleh hutang atau seberapa besar utang perusahaan berpengaruh terhadap pengelolaan aktiva. Semakin tinggi rasio ini maka pendanaan dengan utang semakin banyak, maka semakin sulit bagi 
Sari, et al/Jurnal Ekonomi Syariah Teori dan Terapan Vol. 6 No. 10 Oktober 2019: 2008-2023; FAKTORFAKTOR YANG MEMPENGARUHI NILAI PERUSAHAAN PADA PERUSAHAAN PERDAGANGAN, JASA DAN INVESTASI YANG TERDAFTAR DI ISSI

perusahaan untuk memperoleh tambahan pinjaman karena dikhawatirkan perusahaan tidak mampu menutupi utang-utangnya dengan aktiva yang dimilikinya. Sebaliknya semakin rendah rasio ini maka semakin kecil perusahaan dibiayai dari utang. Standar pengukuran untuk menilai baik tidaknya rasio perusahaan digunakan rasio ratarata perusahaan yang sejenis. (Gunawan, 2013:69)

\section{Total Asset Turnover Ratio}

Total Assets Turnover menurut Sutrisno (2009:221) "Merupakan ukuran efektifitas pemanfaatan aktiva dalam menghasilkan penjualan". Semakin besar perputaran aktiva semakin efektif perusahaan mengelola aktivanya. Dan rasio ini juga menunjukan bagaimana sumberdaya telah dimanfaatkan secara optimal. Total Assets Turnover menurut Syamsuddin (2009:73) "Mengukur berapa kali total aktiva perusahaan menghasilkan penjualan", Ini juga dapat diartikan Total Assets Turnover mengukur perputaran semua aktiva yang dimiliki perusahaan dan mengukur berapa jumlah penjualan yang diperoleh dari tiap rupiah aktiva.

\section{METODE PENELITIAN}

\section{Pendekatan Penelitian}

Pendekatan yang digunakan
dalam penelitian ini adalah
menggunakan pendekatan kuantitatif. Variabel-variabel yang digunakan pada penelitian ini dibagi menjadi dua kelompok variabel, yaitu variabel eksogen yang terdiri dari kepemilikan manajerial,
Return on Equity (ROE), Current Ratio (CR), Debt to Assets Ratio (DAR), dan Total Assets Turnover (TATO), sedangkan variabel endogen yang digunakan yaitu nilai perusahaan yang diproksikan dengan Tobin's Q.

\section{Kepemilikan Manajerial}

Menurut Diyah dan Eman (2009) kepemilikan manajerial adalah persentase kepemilikan saham oleh direktur, manajer, anggota komite, dan sejumlah pihak yang secara langsung dipengaruhi oleh proses pengambilan keputusan. Rumus menghitung kepemilikan manajerial dituliskan dalam persamaan 1

$\mathrm{KM}=\frac{\text { kepemilikan saham manajerial }}{\text { total saham beredar }} \times 100 \%$

\section{Return on Equity}

Menurut Irham (2012:98) Return on Equity merupakan rasio yang digunakan untuk mengkaji sejauh mana suatu perusahaan mempergunakan sumber daya yang dimiliki untuk mampu memberikan laba atas ekuitas. Rumus menghitung return on equity dituliskan dalam persamaan 2 .

$R O E=\frac{\text { Laba Bersih }}{\text { Total Ekuitas }} \times 100 \%$

\section{Current Ratio}

Menurut Moeljadi (2006:48) Current Ratio menunjukkan kemampuan perusahaan untuk memenuhi kewajiban keuangannya yang harus segera dibayar dengan menggunakan hutang lancer. Rumus menghitung current ratio dituliskan dalam persamaan 3 .

$C R=\frac{\text { Aktiva Lancar }}{\text { Utang Lancar }} x 100 \%$

\section{Debt to Assets Ratio}


Sari, et al/Jurnal Ekonomi Syariah Teori dan Terapan Vol. 6 No. 10 Oktober 2019: 2008-2023; FAKTORFAKTOR YANG MEMPENGARUHI NILAI PERUSAHAAN PADA PERUSAHAAN PERDAGANGAN, JASA DAN INVESTASI YANG TERDAFTAR DI ISSI

Menurut Syamsuddin (2006:30)

Debt to Asset Ratio menunjukkan kemampuan seberapa besar jumlah aktiva perusahaan yang dibiayai dengan total hutang perusahaan. Rumus menghitung debt to asset ratio dituliskan dalam persamaan 4 .

$D A R=\frac{\text { Total Utang }}{\text { Total Aset }} \times 100 \%$

\section{Total Assets Turnover Ratio}

Menurut Kasmir (2012:184) total assets turnover ratio merupakan rasio yang digunakan untuk perputara semua aktiva yang dimiliki perusahaan dan mengukur berapa jumlah penjualan yang diperoleh dari tiap rupiah aktiva. Rumus menghitung total asset turnover ratio dituliskan dalam persamaan 5.

TATO $=\frac{\text { Penjualan }}{\text { Total Aktiva }} \times 100 \%$

\section{Nilai Perusahaan}

Menurut Davidson (2002) Nilai perusahaan diproksikan dengan menggunakan Tobin's $Q$. Semakin tinggi nilai Tobin's $Q$, maka akan berdampak pada semakin baiknya tingkat kepercayaan pasar atas prospek perusahaan pada masa yang akan datang. Karena apabila nilai perusahaan tinggi mengindikasikan tingkat kemakmuran investor yang tinggi. Rumus menghitung Tobin's $Q$ dituliskan dalam persamaan 6.

Tobin's $Q=\frac{(M E+D)}{\mathrm{TA}}$

\section{Jenis dan Sumber Data}

Jenis data yang digunakan dalam penelitian ini adalah data sekunder yang berbentuk data panel karena observasi dilakukan pada beberapa perusahaan perdagangan, jasa dan investasi selama rentang waktu 2013-2017. Data variabel eksogen yang digunakan diperoleh dari annual report masing-masing perusahaan terkait. Sedangkan data harga diperoleh dari situs (www.finance.yahoo.com).

\section{Populasi dan Sampel}

Populasi yang digunakan dalam penelitian ini adalah perusahaan dalam sektor perdagangan, jasa dan investasi yang terdaftar di Indeks Saham Syariah (ISSI) Adapun teknik pengambilan sampel dalam penelitian ini menggunakan purposive sampling dengan kriteria sebagai berikut:

1. Perusahaan dalam sektor perdagangan, jasa dan investasi yang aktif diperdagangkan di Bursa Efek Indonesia dan yang terdaftar di Indeks Saham Syariah Indonesia selama periode 2013-2017

2. Perusahaan yang melaporkan laporan keuangan yang telah di audit pada periode 2013-2017 secara rutin dalam website resmi Bursa Efek Indonesia

3. Perusahaan yang melaporkan variabel kepemilikan manajerial di laporan keuangan selama periode 2013-2017

Berdasarkan kriteria diatas, diperoleh 14 perusahaan sebagai sampel penelitian. Dengan 14 perusahaan yang diobservasi selama lima periode, maka akan ada 70 total observasi dalam penelitian ini. Adapun daftar perusahaan tersebut terangkum dalam tabel 1 .

Tabel 1.

\section{Daftar Sampel Perusahaan}


Sari, et al/Jurnal Ekonomi Syariah Teori dan Terapan Vol. 6 No. 10 Oktober 2019: 2008-2023; FAKTORFAKTOR YANG MEMPENGARUHI NILAI PERUSAHAAN PADA PERUSAHAAN PERDAGANGAN, JASA DAN INVESTASI YANG TERDAFTAR DI ISSI

\begin{tabular}{|c|l|}
\hline KODE & \multicolumn{1}{|c|}{ NAMA PERUSAHAAN } \\
\hline ACES & PT. Ace Hardware Indonesia Tbk. \\
\hline AKRA & PT. AKR Corporindo Tbk. \\
\hline BMTR & PT. Global Mediacom Tbk. \\
\hline ERAA & PT. Erajaya Swasembada Tbk. \\
\hline INPP & $\begin{array}{l}\text { PT. Indonesian Paradise Property } \\
\text { Tbk. }\end{array}$ \\
\hline JTPE & PT. Jasuindo Tiga Perkasa Tbk. \\
\hline MTDL & PT. Metrodata Electronics Tbk. \\
\hline PGLI & $\begin{array}{l}\text { PT. Pembangunan Graha Lestari } \\
\text { Indah }\end{array}$ \\
\hline RANC & PT. Supra Boga Lestari Tbk. \\
\hline SHID & PT. Hotel Sahid Jaya International \\
\hline SONA & $\begin{array}{l}\text { PT. Sona Topas Tourism Industry } \\
\text { Tbk. }\end{array}$ \\
\hline TIRA & PT. Tira Austenite Tbk \\
\hline UNTR & PT. United Tractors Tbk. \\
\hline WICO & $\begin{array}{l}\text { PT. Wicaksana Overseas } \\
\text { International }\end{array}$ \\
\hline
\end{tabular}

Sumber : Bursa Efek Indonesia

Teknik Analisis Data

Penelitian ini menggunakan dengan teknik analisis data regresi data panel untuk mengukur pengaruh corporate governance dan faktor fundamental terhadap nilai perusahaan. Menurut Widarjono (2007) data yang digunakan dalam analisis panel merupakan gabungan antara data time series dan cross section. Proses analisis regresi data panel dilakukan menggunakan aplikasi Eviews 9. Model tersebut dituliskan dalam model persamaan 7

$Y=\beta_{i}+\beta_{1} K M_{i t}+\beta_{2} R O E_{i t}+\beta 3 C R_{3 i} i+\beta_{4} D A R_{4 i t}+\beta_{5} T A$ $\mathrm{TO}_{5 i t}+\mathrm{e}$.

Regresi data panel umumnya memiliki tiga alternatif model yang dapat digunakan yaitu Common Effect Models

(CEM), Fixed Effect Models (FEM) dan Random Effect Models (REM).

Untuk menentukan model mana yang terbaik antara model CEM, FEM atau REM maka perlu dilakukan beberapa teknik analisis lebih lanjut.

a. Uji Chow, menurut Ajija, dkk (2011:5253) uji chow untuk menentukan model antara CEM atau FEM sebagai estimasi model yang lebih baik. Jika nilai probabilitas uji $<0,05$ (signifikan) maka yang dipilih adalah model FEM

b. Uji Hausman, menurut Ghozali dan Ratmono (2013:289) uji hausman untuk menentukan antara FEM dan REM sebagai estimasi model yang lebih baik. Jika nilai probabilitas uji > 0,05 (signifikan) maka yang dipilih adalah model REM

\section{Uji Asumsi Klasik}

Setelah memilih model uji regresi data panel yang terbaik, selanjutnya perlu dilakukan uji asumsi klasik. Uji asumsi klasik meliputi uji normalitas, uji heteroskedastisitas dan uji multikolinearitas.

Uji normalitas dapat diketahui dengan melihat penyebaran data (titik) pada sumbu diagonal dari grafik atau dengan histogram dari residualnya. Kriteria pengambilan keputusan yaitu data berdistribusi normal jika nilai Jarque-Bera lebih kecil dan nilai Chi-Square dan $\mathrm{p}$ value > 0,05 (Imam Ghozali, 2006)

Uji heteroskedasitas dapat diketahui dengan melihat grafik plot. Apabila hasil heteroskedastisitas 
Sari, et al/Jurnal Ekonomi Syariah Teori dan Terapan Vol. 6 No. 10 Oktober 2019: 2008-2023; FAKTORFAKTOR YANG MEMPENGARUHI NILAI PERUSAHAAN PADA PERUSAHAAN PERDAGANGAN, JASA DAN INVESTASI YANG TERDAFTAR DI ISSI

menunjukkan bahwa titik-titik pada grafik menyebar dan tidak membentuk pola khusus maka tidak terjadi heteroskedastisitas (Wijaya dalam Sarjono, 2009:124)

Uji multikolinearitas dapat diketahui apabila nilai korelasi kurang dari 0,8 maka model regresi antar variabel independen tidak memiliki hubungan korelasi (tidak terjadi adanya multikolinearitas). (Ghozali, 2006:105-106)

\section{Uji Hipotesis}

Uji † mengukur pengaruh masingmasing variabel bebas terhadap variabel terikat secara parsial. Jika nilai signifikansi uji $\dagger<0,05,0,1$ maka $\mathrm{H}_{0}$ diterima atau hipotesis penelitian ditolak. Sebaliknya, jika nilai signifikansi uji $\dagger<0,05,0,1$ maka $H_{0}$ ditolak dan menerima hipotesis penelitian (Windarjono, 2015:284).

Uji $f$ mengukur pengaruh semua variabel bebas terhadap variabel terikat secara bersamaan. Jika nilai signifikansi uji f > 0,05 maka $\mathrm{H}_{0}$ diterima atau hipotesis penelitian ditolak. Sebaliknya, jika nilai signifikansi uji $f<0,05$ maka $\mathrm{H}_{0}$ ditolak dan menerima hipotesis penelitian (Windarjono, 2015:281)

\section{HASIL DAN PEMBAHASAN}

\section{Tabel 2.}

\section{Hasil Uji Chow}

Redundant Fixed Effect

Test cross-section fixed effects

\begin{tabular}{llll}
\hline \hline Effect Test & Statistic & d.f. & Prob. \\
\hline \hline $\begin{array}{l}\text { Cross- } \\
\text { section F }\end{array}$ & 22.292164 & $(13,51)$ & 0.0000 \\
$\begin{array}{l}\text { Cross- } \\
\text { section Chi- } \\
\text { square }\end{array}$ & 132.962528 & 13 & 0.0000 \\
\hline
\end{tabular}

Sumber: data olahan Eviews 9.0
Berdasarkan hasil uji chow tabel 2 diatas menunjukkan nilai probabilitas sebesar 0,0000 dimana $<0,05$ maka model terbaik yang digunakan yaitu FEM

Tabel 3.

Uji Hausman

Correlated Random Effects - Hausman Test

Test cross-section random effects

\begin{tabular}{llll}
\hline \hline $\begin{array}{l}\text { Test } \\
\text { Summary }\end{array}$ & $\begin{array}{l}\text { Chi-Sq. } \\
\text { Statistic }\end{array}$ & $\begin{array}{l}\text { Chi- } \\
\text { Sq. } \\
\text { d.f. }\end{array}$ & Prob. \\
\hline \hline $\begin{array}{l}\text { Cross- } \\
\text { section } \\
\text { random }\end{array}$ & 14.067249 & 5 & 0.0152 \\
\hline
\end{tabular}

Sumber :data olahan Eviews 9.0

Berdasarkan hasil uji hausman tabel 3 diatas menunjukkan nilai probabilitas sebesar 0,0152 dimana < 0,05 maka model terbaik yang digunakan yaitu FEM

\section{Uji Asumsi Klasik}

\section{Uji Normalitas}

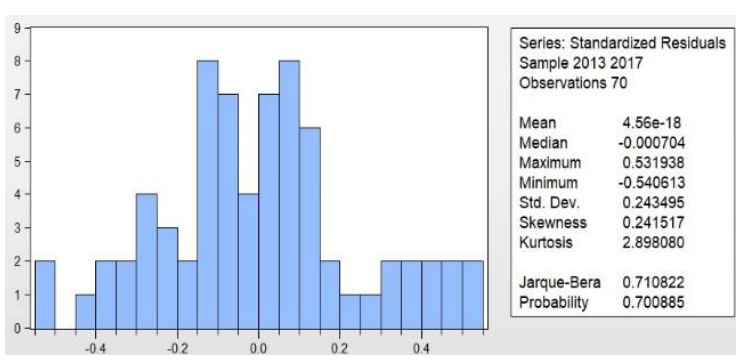

Gambar 2.

\section{Uji Normalitas}

Berdasarkan gambar 2 histrogram diatas menunjukkan bahwa nilai JarqueBera sebesar 0.710822 sementara nilai ChiSquare tabel sebesar 11,1 yang berarti nilai Jarque-Bera > nilai Chi-Square $(0.710822>11,1)$ dengan $p$-value sebesar 0.700885 dimana nilai probabilitas $>0,05$. Sehingga dapat disimpulkan bahwa data penelitian berdistribusi normal. 
Sari, et al/Jurnal Ekonomi Syariah Teori dan Terapan Vol. 6 No. 10 Oktober 2019: 2008-2023; FAKTORFAKTOR YANG MEMPENGARUHI NILAI PERUSAHAAN PADA PERUSAHAAN PERDAGANGAN, JASA DAN INVESTASI YANG TERDAFTAR DI ISSI

Uji Heterokedastisitas

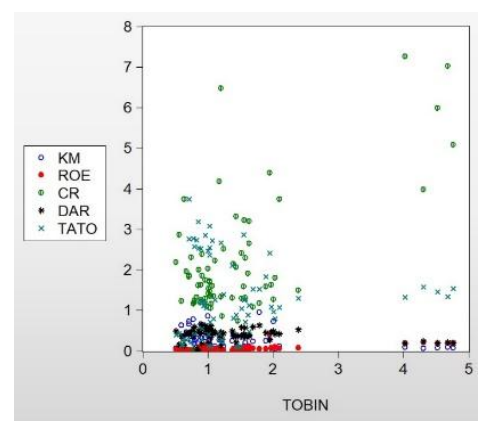

Gambar 3.

Uji Heterokedastisitas

Berdasarkan gambar

3

menunjukkan bahwa titik tidak membentuk pola tertentu dan menyebar sehingga dapat disimpulkan bahwa tidak terjadi gejala heteroskedastisitas

Uji Multikolinearitas

Tabel 4.

Uji Multikolinearitas

\begin{tabular}{lllll}
$K M$ & ROE & CR & DAR & TATO \\
\hline \hline
\end{tabular}

\begin{tabular}{cccccc} 
& 0.0532 & 0.0284 & 0.0016 & 0.01397 & 0.0010 \\
KM 27 & 91 & 87 & 6 & 45 \\
& \multicolumn{5}{c}{-} \\
0.0284 & 0.6444 & 0.00643 & 0.0382 & 0.0115 \\
ROE91 & 91 & 6 & 86
\end{tabular}

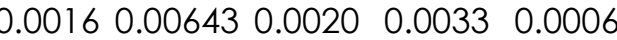

$\begin{array}{llllll}\text { CR } & 87 & 6 & 61 & 34 & 41\end{array}$

$\begin{array}{llllll}\text { DA } & 0.01397 & 0.0382 & 0.0033 & 0.1520 & 0.0068\end{array}$

$\begin{array}{llllll}R & 6 & 94 & 34 & 38 & 78\end{array}$

$\begin{array}{llllll}\text { TAT } & 0.0010 & 0.0115 & 0.0006 & 0.0068 & 0.0090\end{array}$

$\begin{array}{llllll}O & 45 & 86 & 41 & 78 & 29\end{array}$

0.013050 .062980 .006590 .076310 .01668

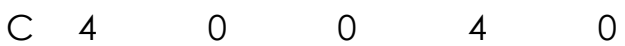

Berdasarkan tabel 4 di atas, terlihat

bahwa hasil regresi memiliki nilai coefficient covariance matrix kurang dari 0,8 . Maka dari hasil diatas dapat disimpulkan bahwa model regresi ini tidak terjadi adanya multikolinearitas

Tabel 5.

\begin{tabular}{lllll}
\multicolumn{5}{c}{$\begin{array}{l}\text { Hasil Analisis Regresi Data Panel - Fixed } \\
\text { Effect Model }\end{array}$} \\
\hline $\begin{array}{lllll}\text { Varia } \\
\text { ble }\end{array}$ & $\begin{array}{l}\text { Coeffici } \\
\text { ent }\end{array}$ & $\begin{array}{l}\text { Std. } \\
\text { Error }\end{array}$ & $\begin{array}{l}\text { t- } \\
\text { Statisti } \\
\text { c }\end{array}$ & $\begin{array}{l}\text { Prob } \\
\text { KM }\end{array}$ \\
& - & & - & \\
\hline & 0.39554 & 0.2307 & 1.7144 & 0.09 \\
& 0 & 10 & 44 & 25 \\
ROE & 2.06071 & 0.8028 & 2.5669 & 0.01 \\
& 9 & 02 & 09 & 32 \\
CR & 0.06529 & 0.0454 & 1.4380 & 0.15 \\
& 4 & 03 & 89 & 65 \\
DAR & 0.07020 & 0.3899 & 0.1800 & 0.85 \\
& 1 & 21 & 40 & 78 \\
TATO & - & & - & \\
& 0.07510 & 0.0950 & 0.7904 & 0.43 \\
& 9 & 21 & 41 & 29 \\
C & 1.30969 & 0.2725 & 4.8062 & 0.00 \\
& 9 & 00 & 41 & 00 \\
\hline \hline
\end{tabular}

Sumber: data olahan Eviews 9.0

Berdasarkan tabel 5 hasil

pengujian analisis regresi data panel diatas, kemudian dapat ditulis persamaan model regresi sebagai berikut:

TOBIN $_{\text {it }}=-0.395540$ KMit $^{2} 2.060719$ ROEit + 0.065294CRit $\quad+\quad 0.070201$ DARit-

0.075109TATOit + 1.309699

\section{Uji Hipotesis}

Uji Simultan (F-test)

Tabel 6.

Hasil Uji Simultan (F-test)

F-statistic $\quad 40.28548$

Sumber: data olahan Eviews 9.0

Berdasarkan tabel 6 di atas dapat diketahui bahwa nilai signifikansi Prob (Fstatistic) sebesar $0,000000>0,05$. Sehingga kepemilikan manajerial, Return On Equity, Current Ratio, Debt To Asset Ratio, Total Assets Turnover Ratio secara simultan berpengaruh signifikan terhadap nilai perusahaan (Tobin's Q)

Uji Parsial (T-test)

Tabel 7.

Hasil Uji T (Parsial)

\begin{tabular}{|c|c|c|c|}
\hline Variab & Coef & Probabilit & Keteranga \\
\hline
\end{tabular}


Sari, et al/Jurnal Ekonomi Syariah Teori dan Terapan Vol. 6 No. 10 Oktober 2019: 2008-2023; FAKTORFAKTOR YANG MEMPENGARUHI NILAI PERUSAHAAN PADA PERUSAHAAN PERDAGANGAN, JASA DAN INVESTASI YANG TERDAFTAR DI ISSI

\begin{tabular}{|c|c|c|c|}
\hline el & & $y$ & $\mathbf{n}$ \\
\hline KM & $\begin{array}{l}- \\
0.39554 \\
0\end{array}$ & 0.0925 & $\begin{array}{l}\mathrm{H}_{1} \\
\text { diterima }\end{array}$ \\
\hline ROE & $\begin{array}{l}2.06071 \\
9\end{array}$ & 0.0132 & $\begin{array}{l}\mathrm{H}_{1} \\
\text { diterima }\end{array}$ \\
\hline$C R$ & $\begin{array}{l}0.06529 \\
4\end{array}$ & 0.1565 & $\mathrm{H}_{1}$ ditolak \\
\hline DAR & $\begin{array}{l}0.07020 \\
1\end{array}$ & 0.8578 & $\mathrm{H}_{1}$ ditolak \\
\hline TATO & $\begin{array}{l}- \\
0.07510 \\
9\end{array}$ & 0.4329 & $\mathrm{H}_{1}$ ditolak \\
\hline
\end{tabular}

Sumber: Data Olahan Eviews 9

Berdasarkan tabel 7 diatas dapat diketahui variabel kepemilikan manajerial berpengaruh negatif signifikan, variabel Return On Equity berpengaruh positif signifikan, variabel Current Ratio dan Debt to Asset Ratio berpengaruh positif tidak signifikan serta Total Asset Turnover Ratio berpengaruh negatif tidak signifikan terhadap nilai perusahaan (Tobin's Q)

\section{Analisis Koefisien Determinasi ( $\left.\mathbf{R}^{2}\right)$}

Hasil analisis regresi data panel menunjukkan nilai $R^{2}$ ( $R$-squared) sebesar 0,934290 (93,42\%). Dapat disimpulkan bahwa variabel eksogen meliputi kepemilikan manajerial, Return On Equity, Current Ratio, Debt to Asset Ratio, Total Assets Turnover Ratio dapat menjelaskan pengaruhnya terhadap nilai perusahaan (Tobin's Q) sebesar 93,42\% dan sisanya sebesar $6,58 \%$ dijelaskan variabel lain diluar variabel eksogen yang digunakan dalam penelitian ini.

\section{Pengaruh Kepemilikan Manajerial Terhadap Nilai Perusahaan \\ Kepemilikan manajerial} berpengaruh negatif signifikan terhadap nilai perusahaan sejalan dengan penelitian Welim (2013), Sukirni (2012), Budianto dan Payamta (2014). Hal tersebut menunjukkan bahwa semakin besar kepemilikan manajerial dalam struktur pemegang saham akan menyebabkan rawan tindakan yang lebih mementingkan kepentingan manajer dari pada kepentingan pemegang saham, hal ini berdampak pada reaksi negatif dalam meningkatkan nilai perusahaan. Manajer sebagai pengelola perusahaan mempunyai informasi lebih banyak dari pemegang saham. Manajer yang mempunyai informasi lebih banyak dari pemegang saham dapat menimbulkan opportunistic.(Horme dan Wachowicz. 2005). Kepemilikan saham yang signifikan oleh manajer menandakan bahwa manajer memiliki status ganda yaitu sebagai pemilik dan pengelola perusahaan. Sebagai pengelola perusahaan manajer juga dapat bertindak untuk memutuskan segala sesuatu yang berkaitan dengan perusahaan. Peran status ganda ini membuat manajer seolah-olah mengawasi dirinya sendiri, sehingga memudahkan manajer mencapai kepentingan pribadinya bukan kepentingan perusahaan

Pengaruh Return on Equity Terhadap Nilai Perusahaan

Return on Equity berpengaruh positif signifikan terhadap nilai perusahaan sejalan dengan penelitian yang dilakukan Sabrin (2016), Chowdhury (2010), Kusuma 
Sari, et al/Jurnal Ekonomi Syariah Teori dan Terapan Vol. 6 No. 10 Oktober 2019: 2008-2023; FAKTORFAKTOR YANG MEMPENGARUHI NILAI PERUSAHAAN PADA PERUSAHAAN PERDAGANGAN, JASA DAN INVESTASI YANG TERDAFTAR DI ISSI

(2009) dan Rahmantio (2018). Hal ini menunjukkan bahwa total ekuitas atau modal yang tinggi berbanding lurus dengan tingkat produktivitas perusahaan yang dialokasikan menjadi keuntungan yang tinggi. Dengan kata lain, manajemen perusahaan berhasil memaksimalkan ekuitas yang diberikan oleh investor sehingga meningkatkan kepercayaan investor untuk menanamkan modalnya ke perusahaan yang bisa mempengaruhi nilai perusahaan. Peningkatan ROE disebabkan karena banyaknya perusahaan yang mengalami keuntungan dikarenakan jumlah modal sendiri mengalami peningkatan, sehingga menghasilkan nilai ROE besar yang menunjukkan bahwa perusahaan mampu memperoleh laba bagi para pemegang saham. Dampaknya dapat mendorong investor untuk meningkatkan jumlah modal yang disetorkan. Hal ini dapat mengakibatkan peningkatan jumlah permintaan terhadap saham perusahaan sehingga mendorong harga saham naik dan nilai perusahaan pun menjadi tinggi

Pengaruh Current Ratio Terhadap Nilai Perusahaan

Current Ratio berpengaruh positif tidak signifikan terhadap nilai perusahaan sejalan dengan penelitian yang dilakukan Chen et. al. (2011), Corry Winda Anzlina dan Rustam (2013), Adelina (2014). Hal ini menunjukkan bahwa current ratio tidak menjadi salah satu faktor pertimbangan investor untuk melihat nilai perusahaan tersebut. Menurut Sawir (2005:9) menyatakan bahwa current ratio yang rendah akan berdampak pada penurunan nilai perusahaan, namun jika terlalu tinggi maka akan dapat mengurangi perusahaan karena banyaknya dana yang menganggur.Dengan kata lain, seorang investor yang akan melakukan investasi tidak perlu memperhatikan faktor current ratio yang dimiliki perusahaan karena rasio ini hanya menunjukkan kemampuan perusahaan untuk menutupi hutang lancer dengan aktiva lancar.

\section{Pengaruh Debt to Asset Ratio Terhadap Nilai Perusahaan}

Debt to Asset Ratio berpengaruh positif tidak signifikan terhadap nilai perusahaan sejalan dengan penelitian yang dilakukan Amin (2018). Secara umum struktur modal sebuah perusahaan, yang diwakili oleh rasio keuangan Debt to Asset Ratioternyata tidak dapat mempengaruhi nilai perusahaan yang tercermin dalam imbal hasil sahamnya secara signifikan. Banyaknya faktor fundamental lain selain struktur modal suatu perusahaan yang dapat mempengaruhi nilai sebuah perusahaan mungkin merupakan salah satu faktor penyebab tidak signifikannya hubungan antarastruktur modal perusahaan terhadap imbal hasil sahamnya, misalnya saja tingkat profitabilitas yang seringkali dinilai lebih relevan untuk dijadikan sebagai faktor pertimbangan dalam menilai sebuah perusahaan.Adapun menurut Kasmir 
Sari, et al/Jurnal Ekonomi Syariah Teori dan Terapan Vol. 6 No. 10 Oktober 2019: 2008-2023; FAKTORFAKTOR YANG MEMPENGARUHI NILAI PERUSAHAAN PADA PERUSAHAAN PERDAGANGAN, JASA DAN INVESTASI YANG TERDAFTAR DI ISSI

(2014:156) "Apabila rasio Debt to Asset Ratio (DAR) tinggi, artinya pendanaan dengan utang semakin banyak, maka semakin sulit bagi perusahaan untuk memperoleh tambahan pinjaman karena dikhawatirkan perusahaan tidak mampu menutupi hutang-hutangnya dengan aktiva lancar yang dimilikinya. Demikian pula apabila rasionya rendah, semakin kecil perusahaan dibiayai dengan utang".

Pengaruh Total Asset Turnover Ratio Terhadap Nilai Perusahaan

Total Asset Turnover Ratio berpengaruh negatif tidak signifikan terhadap nilai perusahaan sejalan dengan penelitian yang dilakukan SInaga (2011). Pada penelitian ini, perusahaanperusahaan cenderung lambat dalam mengerjakan proyek-proyeknya dan penjualannya, sehingga aset perusahaan kurang digunakan secara efisien. Meskipun hasilnya tidak signifikan, bukan berarti bahwa investor dapat mengabaikan rasio TATO suatu perusahaan, seringkali adanya kondisi rasio antar perusahaan yang berbeda karena perbedaan waktu perolehan aset, misalnya aset yang baru lebih efisien karena pengaruh teknologi dan jika keadaan inflasi, aset bisa menjadi lebih mahal. Hasil negatif dalam penelitian ini didapatkan karena TATO yang rendah mengindikasikan bahwa suatu perusahaan tidak bisa memanfaatkan aktiva yang dimiliki untuk mengalokasikan asetnya dengan baik.

\section{v. SIMPULAN}

Berdasarkan hasil penelitian yang telah dilakukan menunjukkan bahwa kepemilikan manajerial, Return On Equity, Current Ratio, Debt To Asset Ratio, Total Assets Turnover Ratio secara simultan berpengaruh signifikan terhadap nilai perusahaan (Tobin's Q). Secara parsial variabel kepemilikan manajerial berpengaruh negatif signifikan, variabel Return on Equity berpengaruh positif signifikan, variabel Current Ratio dan Debt to Asset Ratio berpengaruh positif tidak signifikan serta Total Asset Turnover Ratio berpengaruh negatif tidak signifikan terhadap nilai perusahaan (Tobin's Q) pada perusahaan perdagangan, jasa dan investasi.

Saran yang dapat diberikan dari penelitian ini bagi emiten atau perusahaan dapat memaksimalkan struktur kepemikan saham atau manajer agar menjadi sebuah motivasi yang optimal dan dapat mengontrol dan meningkatkan profitabilitas bagi pemegang saham yang dapat mempengaruhi nilai perusahaan. Bagi investor dapat berinvestasi pada perusahaan perdagangan, jasa dan investasi khususnya yang terdaftar di ISSI karena menjadi salah satu dari lima sektor yang menyumbang PDB terbesar, dengan kata lain salah satu sektor yang mempunyai prospek keuntungan yang bagus. Serta bagi peneliti selanjutnya dapat menambahkan sampel penelitian agar hasilnya lebih baik dan menambah 
Sari, et al/Jurnal Ekonomi Syariah Teori dan Terapan Vol. 6 No. 10 Oktober 2019: 2008-2023; FAKTORFAKTOR YANG MEMPENGARUHI NILAI PERUSAHAAN PADA PERUSAHAAN PERDAGANGAN, JASA DAN INVESTASI YANG TERDAFTAR DI ISSI

variabel lain yang berasal dari corporate governance

\section{DAFTAR PUSTAKA}

Ajija, Shochrul Rohmatul, dkk. 2011. Cara Cerdas Menguasai Eviews. Jakarta: Salemba Empat

Bodie Z, Kane A, Marcus A. J. 2009. Investments: eight edition. McGraw Hill. USA

Burhanuddin. 2008. Pasar Modal Syariah. Jakarta: UII Press.

Davidson, I., Leledakis, G., \& Okunev, J. (2002). Tobin's $Q$ and the Cross Sectional Variation of Stock Returns: Evidence from the London Stock Exchange. Loughborough University Banking Centre.

Denis, D. K., \& McConnell, J. J. (2003). International

Corporate Governance. Journal of Financial and Quantitative Analysis, 38(1), 136

Diyah dan Erman. 2009. "Pengaruh Struktur Kepemilikan Terhadap Nilai Perusahaan: Keputusan Keuangan Sebagai Variabel Intervening". (JurnalPerbanas)

Fahmi, Irham. (2012). Pengantar Pasar Modal. Penerbit Alfabeta: Bandung

Fred, W. J., \& Copeland, T. E. (1992). Managerial Finance. 9th Editon. The Dryden Press Orlando Florida USA.

Ghozali, I. (2006). Aplikasi Analisis Multivariate dengan Program SPSS.
Badan Penerbit Universitas Diponegoro.

Ghozali, I., \& Ratmono, D. (2013). Analisis Multivariat dan Ekonometrika: Teori, Konsep, dan Aplikasi dengan EVIEWS 8. Semarang: Badan Penerbit Universitas Diponegoro.

Gunawan, A., \& Wahyuni, S. F. (2014). Pengaruh rasio keuangan terhadap pertumbuhan laba pada perusahaan perdagangan di Indonesia. Jurnal IImiah Manajemen dan Bisnis, 13(1).

Hamdani. (2016). Good Corporate Governance: Tinjauan Etika dalam Praktik Bisnis. Jakarta: Mitra Wacana Media.

Hanafi, Mamdun M. dan Abdul Halim, (2008), Analisis Laporan Keuangan, EdisiKetiga, Penerbit ISBN, Jakarta.

Herlina, D. (2015). Analisis Current Ratio, Total Asset Turnover, Receivable Turnover Ratio dan Debt to Equity Ratio Terhadap Return on Equity (ROE) Pada Perusahaan Jasa Sub. Sektor Restoran, Hotel, Dan Pariwisata yang Terdaftar Di Bei Periode 2010-2013 (Doctoral dissertation, Politeknik Negeri Sriwijaya).

Jensen, M. C., \& Meckling, W. H. (1976). Theory of the firm: Managerial behavior, agency costs and ownership structure. Journal of financial economics, 3(4), 305-360.

Kahfi, M. F., Pratomo, D., \& Aminah, W. (2018). Pengaruh Current Ratio, 
Sari, et al/Jurnal Ekonomi Syariah Teori dan Terapan Vol. 6 No. 10 Oktober 2019: 2008-2023; FAKTORFAKTOR YANG MEMPENGARUHI NILAI PERUSAHAAN PADA PERUSAHAAN PERDAGANGAN, JASA DAN INVESTASI YANG TERDAFTAR DI ISSI

Debt To Equity Ratio, Total Assets Turnover Dan Return On Equity Terhadap Nilai Perusahaan (Studi Kasus Pada Perusahaan Manufaktur Sektor Food And Beverage Yang Terdaftar Di Bursa Efek Indonesia Pada Tahun 20112016). eProceedings of Management, 5(1).

Kasmir. 2012. Analisis Laporan Keuangan. Jakarta: Raja Grafindo Parsada.

Made Pratiwi Sisca. 2011. Pengaruh Struktur Modal dan Struktur Kepemilikan terhadap Free Cash Flow dan Kebijakan Dividen pada Perusahaan Perusahaan yang Go Public di Bursa Efek Indonesia. Universitas Udayana.

Magness, V. (2008). Who are the stakeholders now? An empirical examination of the Mitchell, Agle, and Wood theory of stakeholder salience. Journal of business ethics, 83(2), 177-192.

Moeljadi. 2006. Manajemen Keuangan: Pendekatan Kuantitatif dan Kualitatif. Malang: Bayumedia.

Ningtyas, Kilat Liliani. 2014. Pengaruh Good Corporate Governanceterhadap Nilai Perusahaan (Studi pada Perusahaan yang terdaftar di Jakarta Islamic Index tahun 20102013). Jurnal Administrasi Bisnis. 17 (1)

Rahmantio, I., Saifi, M., \& Nurlaily, F. (2018). Pengaruh Debt to Equity Ratio, Return On Equity, Return On Asset dan Ukuran Perusahaan terhadap Nilai Perusahaan (Studi pada Perusahaan Pertambangan yang Terdaftar di Bursa Efek Indonesia Tahun 2012-2016). Jurnal Administrasi Bisnis, 57(1).

Sabrina, Anindhita. 2010."Pengaruh Corporate Governance dan Struktur Kepemilikan terhadap Kinerja Perusahaan". Skripsi. Semarang. Universitas Diponegoro.

Sarjono, Haryadi., dan Winda Julianita. 2011. SPSS vS Lisrel: Sebuah Pengantar,Aplikasi untuk Riset. Jakarta: Penerbit Salemba Empat.

Sawir, A. (2005). Analisis Kinerja Keuangan Dan Perencanaan Kevangan Perusahaan.

Stoner, James A.F., R. Edward Freeman, and Daniel R.Gilbert (1995), Management, 6thed., New Jersey: Englewood Cliff

Syamsuddin, Lukman. 2006. Manajemen Keuangan Perusahaan. Jakarta: PT. Eaja Grafindo Persada

Tjandrakirana DP, R., \& Monika, M. (2014). Pengaruh Kinerja Kevangan Terhadap Nilai Perusahaan Pada Perusahaan Manufaktur yang Terdaftar di Bursa Efek Indonesia. Jurnal Manajemen dan Bisnis Sriwijaya, 12(1), 1-16.

Ujiyantho, M. A., \& Pramuka, B. A. (2007). Mekanisme corporate governance, manajemen laba dan kinerja keuangan. Simposium Nasional Akuntansi X, 10(6). 
Sari, et al/Jurnal Ekonomi Syariah Teori dan Terapan Vol. 6 No. 10 Oktober 2019: 2008-2023; FAKTORFAKTOR YANG MEMPENGARUHI NILAI PERUSAHAAN PADA PERUSAHAAN PERDAGANGAN, JASA DAN INVESTASI YANG TERDAFTAR DI ISSI

Van Horne, J. C., \& Wachowicz, J. M. (2005). Fundamentals of financial management. Pearson Education.

Widarjono, A. (2007). Ekonometrika: teori dan aplikasi untuk ekonomi dan bisnis. Yogyakarta: Ekonisia.
Yuliana, I. (2010). Investasi Produk Kevangan Syariah (Cetakan I). Malang: UIN-Maliki Press. 